\title{
ESL Teachers' Professional Development on Facebook During the Covid-19 Pandemic
}

\author{
R. Al-Jarf
}

\section{Abstract}

Schoolteachers and college instructors from around the world can create or join special Facebook pages (FPs), groups, or clubs for ESL teachers for free. Those FPs are online learning communities that provide opportunities for in-depth peerto-peer interaction, communication, and support. This study aims to give examples of FPs for ESL teachers; identify the kinds of topics and issues posted about the teaching and learning of English as a second/foreign language; find out whether there are special ESL Teachers' Facebook Pages (TFPs) that focus on remote teaching and learning during the Covid-19 Pandemic; whether there are difference in the topics posted in TFPs before and during the Pandemic; and to explore the advantages and shortcomings of TFPs, and their role in teacher's professional development before and during the Covid-19 Pandemic as perceived by a sample of ESL teacher who are members of those pages. 2500 posts from 75 ESL TFPs were analyzed. It was found that $12 \%$ are general TFPs, $42 \%$ target ESL teachers in specific countries, $16 \%$ are devoted to recruitment and job announcements, $38 \%$ are theme-based, and $22 \%$ focus on online/virtual and home-based teaching. The topics that teachers post in the TFPs, teachers' views of the benefits and shortcomings of joining TFPs, and the role of TFPs in their professional development are reported in detail.

Keywords: Covid-19, Facebook Professional Groups, ESL Teachers, Professional Development.
Published Online: December 8, 2021

ISSN: $2736-4534$

DOI : 10.24018/ejedu.2021.2.6.220

R. Al-Jarf

King Saud University, Riyadh, Saudi Arabia.

(e-mail: reima.al.jarf@gmail.com) ORCID ID: 0000-0002-6255-1305

\section{INTRODUCTION}

Many teachers, institutions, centers, organizations, and publishers have created language learning and teaching pages on social media such as Facebook, Twitter, Instagram, Telegram, WhatsApp, WeChat, Google+, Pinterest, Linkedin and others. ESL teachers from around the world can join pages, groups, or clubs on social media for free. A review of the literature has shown numerous studies that have investigated teacher professional development on a variety of social media platforms such as: WeChat (Xue et al., 2021); WhatsApp (Suardika et al., 2020; Allela et al., 2020; Moodley, 2019); Pinterest (Torphy et al., 2020); Twitter (Richards et al., 2020; Al-Jarf, 2020a; Al-Jarf, 2020b; Supovitz et al., 2020; Goodyear et al., 2019; Greenhow et al., 2019; Slagoski, 2019; Lemon \& O’Brien, 2019; Nicholas, et al., 2018; Manson, \& Cordovés, 2018; Benko et al., 2016; Hardy, 2014) and others.

In addition, numerous studies have examined teachers' professional learning communities on social media in numerous disciplines such as: Science (Setiawan \& Phillipson, 2020); physical education (Kinchin \& Bryant, 2015; Harvey \& Carpenter, 2020; Carpenter \& Harvey, 2020; vocational education and training (Andersson \& Köpsén, 2019); occupational therapy (Murray \& Ward, 2019); professional consultants (Chasteen, et al., 2019); translation and language teaching and learning (Al-Jarf, 2020a; Al-Jarf, 2020b) and others.

Moreover, the study of teachers' professional development on social media has been popular in several countries. For example, in Pakistan and Phutan et al. (2019) explored the effect of teacher's digital competence in using social media and digital resources on participating in professional online communities and professional learning. Surveys with 67 teachers from Pakistan and 37 teachers from Bhutan revealed that teacher interaction on social networks and use of digital resources play a central role in introducing teachers to innovative pedagogical practices, knowledge sharing and professional learning.

In Kenya, Bett and Makewa (2020) analyzed teachers' discussions in 647 posts from a Facebook Group called 'Teachers of English.' Results showed that teachers' interactions focused on the teaching of English and Literature, and other education-related issues. The researchers added that Facebook can serve as a potential platform for enhancing teachers' professional development.

In Sweden, Bergviken Rensfeldt et al. (2018) examined a Swedish teacher Facebook group with 13,000 members to find out aspects of the online community that are professionally beneficial and/or valuable for information exchange and social support. Although the participants indicated that Facebook was relatively beneficial to their 
professional development, some characteristics of the Facebook group were disadvantaging, exploitative and/or a disempowering form of technological engagement because Facebook groups expose teachers to some forms of commercialisation of the Facebook exchanges, 'digital labour', and the predominance of individualised reputationdriven behaviours.

A second Swedish study by Lundin et al. (2020) analyzed 79 posts that received more comments than likes in a Swedish teacher thematic Facebook group for professional learning. Findings showed that the 79 posts were formulated as questions and/or requests to attract comments, not only likes. Those posts were organized around four themes: (i) instructionally motivated technical features; (ii) pedagogical ideas and premises; (iii) functionally motivated technical features; and (iv) sharing. The teachers used the thematic Facebook group to share teaching materials and resources and to give and receive emotional and professional support. Such sharing and support meant a shift from working in isolation to joining a professional language teaching and learning community. In the discussion threads, a variety of teacher identities were displayed: active, engaged, expert, or a central group member. The study emphasized the need for strengthening teachers' competencies with regards to using social media platforms to stimulate collective and constructive discussions. But the challenge remains as to how to encourage more teachers to participate in such groups in order to trigger discussions characterised by openness, debate, and constructive criticism.

A third Swedish study by Liljekvist et al. (2021) compared teachers' participation in self-organized Facebook groups in mathematics and Swedish-language education. They analyzed 553 posts from 6 Facebook groups and classified them according to Shulman's knowledge-based framework and systemic functional grammar. Results of the analysis showed that the teachers used "questions" and "offers" more frequently $(88 \%)$ than speech functions and pedagogical content knowledge $(63 \%)$. This means that teachers use these professional learning communities as a professional development resource, focusing their interaction on pedagogical content knowledge. The researchers found similar practices in the math and language Facebook groups.

Moreover, the literature showed some review studies on the use of social media in teacher education and development. For example, Luo et al. (2020) reviewed 23 research articles on social media and professional development in higher education published between 2009 and 2019. Findings suggested that research and practice on social mediasupported professional learning is still in its inception stage. Although social media have the potential for contributing to faculty professional learning, there are still challenges related to sustaining faculty participation and engagement, and navigating the social media space effectively, especially for teachers who are novice social media users. In another study, Iredale et al. (2020) explored what constitutes effective use of social media in supporting the development of new teachers in all sectors of teacher education, including English language teaching in primary, secondary, and lifelong learning. Results of the review revealed issues related to pedagogy, design, and community.

\section{AIMS OF STUDY}

The above literature review has shown that social media sites, especially Facebook, are currently becoming standard tools for professional practices. However, studies by Luo et al. (2020) and Iredale et al. (2020) revealed that research and practice on social media-supported professional learning are in their early stage. Results about the use of social media for community building and enduring professional development are still insufficient. Bedford (2019) added that although Virtual Professional Learning Communities are becoming a more acceptable delivery mode for faculty professional development, effective practices for designing these learning environments have received little attention in the literature. In addition, there is lack of studies in the literature, in general, and in Saudi Arabia, in particular, that investigate the use of social media in the professional development of ESL teachers during the Covid-19 Pandemic. Therefore, the current study aims to: (i) give examples of theme-based FPs for ESL teachers; (ii) identify the kinds of topics and issues posted in TFPs about the teaching and learning of English as a second/foreign language to students of all ages; (iii) find out whether there are special ESL TFPs that focus on remote teaching and learning during the Covid-19 Pandemic; whether the topics discussed in the Covid-19 ESL TFPs before the Pandemic differ from those posted in FTPs during the Pandemic; and (iv) to explore the benefits and shortcomings of participating ESL TFPs and role of ESL TFPs in teacher's professional development before and during the Covid-19 Pandemic as perceived by a sample of ESL teacher who are members of those TFPs.

Results of the current study are of special importance for ESL teachers and professional development stakeholders as FPs, groups, or clubs provide an environment in which professional learning can occur. They will shed light on the benefits of the Facebook learning communities for professional development and teachers' perceptions and experiences interacting in the Facebook virtual professional learning community. TFPs provide ESL teachers with opportunities for in-depth teacher-to-teacher interaction. They provide members with a platform for discussing challenges and building professional skills.

\section{DEFINITION OF PROFESSIONAL DEVELOPMENT}

Professional development 1 refers to ongoing training and education, continuing education, or professional learning and certification that teachers need to succeed in their job. Examples of professional development may include online training programs, college studies, coaching, mentoring, consultation, and certification. Through professional development, teachers can learn new teaching skills to

\footnotetext{
${ }^{1}$ https://www.ahaworldcampus.com/b/what-is-professional-development
} 
become better, more efficient, and successful. Professional development helps teachers feel more confident knowing that they have the necessary skills for performing their job effectively. It provides teachers with new opportunities for getting promoted to a higher position. It aims at improving teachers' knowledge and skills in their area of specialization which will lead to the accomplishment of the desired learning outcomes and improved student learning.

\section{METHODOLOGY}

\section{A. Sample of ESL TFPs}

Since many synonymous terms are used in the literature to refer to professional groups on social media such as online learning communities of practices, online communities of practice, professional learning networks, professional learning communities, social media-supported professional learning, and others, and to avoid duplicates of the same group(s) in the search results, the author searched Facebook using "ESL teachers" only. Thus, a total of 105 ESL TFPs were located. The followers of those ESL TFPs ranged between 17 and 186,000, with a median of 5400 followers. 5 pages with fewer than 100 followers were excluded. Since some FPs have similar names such as "ESL English Teachers", only 75 FPs were selected for the final sample and analyzed.

\section{B. Sample of Posts}

The first 25 posts from each FP, i.e., a total of 2500 posts were selected for content analysis.

\section{Sample of Teacher Members}

A sample of 150 participating ESL teachers were surveyed, i.e., 2 teachers randomly selected from each FP. The sample consisted of teachers of different nationalities, ages, college degrees, years of experience and countries where they teach.

\section{The Questionnaire-Survey}

A questionnaire-survey with open-ended questions was used to explore teachers' views on the advantages and shortcomings of participating in ESL TFPs, their attitudes towards participating in online ESL learning communities on Facebook and the role of joining a TFP in their professional development.

\section{E. Data Collection}

First, all page titles were classified according to the themes they focus on and whether there are special ESL TFPs that focus on teaching and learning ESL during the Covid-19 Pandemic. Second, the sample of posts was analyzed to find out the kinds of topics and issues posted about the teaching and learning of English as a second/foreign language to students of all ages, to find out whether there are special ESL TFPs that focus on remote teaching and learning during the Covid-19 Pandemic, and whether the topics discussed in the Covid-19 ESL TFPs before the Pandemic differ from those posted in the ESL FTPs during the Pandemic. Third, the sample of teachers was individually and privately contacted through Facebook Messenger and each teacher was asked to answer a questionnaire-survey with open ended questions about the advantages and shortcomings of joining an ESL TFP. Teachers who did not respond were replaced by others from the same forum.

\section{F. Data Analysis}

First, all the FP titles in the sample were classified into 5 categories: (i) pages with a general focus, i.e., for all teachers, (ii) pages that are theme-based, i.e., focusing on a specific aspect of language teaching and learning, specific groups of ESL teachers they target, and remote teaching, learning, and working or home-based teaching during the Pandemic; (iii) countries and regions where ESL is taught; (iv) pages that focus on job recruitment and announcement. The number of pages in each category were calculated in percentages.

Second, the sample of posts was analyzed to find out the kinds of topics and issues posted about the teaching and learning of English as a second/foreign language to students of all ages, to find out whether there are topics/posts that focus on remote teaching and learning during the Covid-19 pandemic, and whether the topics discussed in the Covid-19 ESL TFPs before the Pandemic differ from those posted during the Pandemic. Result of the analysis are reported qualitatively as it is more important to find out the kinds of issues posted rather than how many.

Third, teachers' responses to the questionnaire-surveys were classified according to the questions asked and are reported qualitatively, and where necessary are reported quantitatively (in percentages).

\section{RESUlTS AND DisCUSSION}

\section{A. Types of ESL TFPS}

Table I shows that the distribution of the ESL TFPs in the sample is as follows:

1) $12 \%$ are general FPs, i.e., FPs that target all ESL teachers regardless of where they teach, which grade level they teach, whether they are newbies or tenured and so on as in the following pages: ESL teachers; ESL Teachers Community; ESL Teachers Hub; Online ESL Teachers; Teachers' Lounge for online ESL; Teachers of English; Teachers of ESL or EFL Hangout; Teaching Group for ESL Teachers; TEFL Teaching Community

2) $42 \%$ of the pages target a specific group of ESL teachers in specific countries and regions with half of the FPs $(21 \%)$ targeting teachers in or from the Philippines and the other half (21\%) targeting teachers in Vietnam, Brazil, China, International, Ontario, Quebec, America, South Africa, Korea, Britain, and USA.

3) $16 \%$ of the FPs are devoted to recruitment and job announcements as in the following pages: English Teaching Jobs - TEFL, TESOL, ESL, EFL; ESL Teachers Philippines Hiring (ESL, Home-Based, Work from Home); Hired Online ESL Teachers with Job Reviews; Hiring Online Teaching Platforms (Philippine ESL Teachers/Applicants; Online ESL Teaching Jobs; Skilled and Hired Online ESL Teachers Group; TEFL/ESL/ English Teaching Jobs. 
4) $38 \%$ are theme-base FPs with a specific focus on certain grade level, providing support, worksheets, tutorials, games, strategies, tutors, private lessons, volunteer teachers, former teachers, newbies and tenured, tutors, independent, certified, and Cambly courses as in the following examples: All Things China for VIPKid Teachers; ESL/EFL Elementary Teachers; Engaging ELLs - ESL Teaching Resources for K-12; K-12 Bilingual and ESL Teachers; ESL/ESOL Teachers in Secondary; Adult Ed ESL Teachers; EFL/ESL Teachers' Library; English Activities for Teachers; English Learning Centre - Cambly; English Worksheets \& TEFL, TESOL, ESL, EFL; ESL - Free Tutorials for TESOL \& TEFL; Teaching materials \& Job referrals; ESL EFL Teachers/TEFL CELTA DELTA TESOL Instructors Worldwide Group; ESL games and activities; ESL Materials and Resources; ESL Teachers - Practical Teaching Strategies; New Online ESL Teachers Community; Online ESL Teacher Success and Support; Online ESL Teaching: Recruitment, Mentoring \& Support; Professional Development for ESL/EFL/ESOL/ ELL/ESP Teachers; TDSB Virtual School ESL Teachers; Resources for ESL/EFL Teachers; Your English Source: All Things ESL/EFL; Resources for former Online ESL teachers; ESL Teachers of the Philippines (For tenured and newbies); Find ESL Tutors/ESL Learners (Group or Private Lessons Online); Volunteer ESL Teachers; Certified ESL Teachers of the Philippines; Independent Online ESL Teachers.

TABLE I: PERCENTAGE OF THE TYPES OF ESL TFPS FOCUS WITH EXAMPLES

\begin{tabular}{lc}
\hline \hline \multicolumn{1}{c}{ ESL TFPs Focus with Examples* } & $\%$ \\
\hline Pages for ESL teachers in specific country/regions & $42 \%$ \\
\hline Theme-based pages with a specific focus & $38 \%$ \\
\hline Online and home-based teaching & $22 \%$ \\
\hline Recruitment and job announcements & $16 \%$ \\
\hline General pages & $12 \%$ \\
\hline * Some FPs were classified under two or more categories.
\end{tabular}

* Some FPs were classified under two or more categories.

Unlike the present study which analyzed 75 TFPs, prior studies by Impedovo et al. (2019); Bett and Makewa (2020); Bergviken Rensfeldt et al. (2018); and Lundin et al. (2020) focused on one Facebook group and Liljekvist et al. (2021) focused on 6 Facebook groups. Prior studies focused on general as well as thematic Facebook groups, whereas the sample of Facebook groups in the current study focused on general pages, theme-based pages with a specific focus, recruitment and job announcements, pages for ESL teachers in specific country/regions, and online/virtual teaching and recruiting.

\section{B. Types of Topics Posted}

Content analysis showed that members of the TFPs (ESL/EFL teachers, academic directors and coordinators, teachers and administrators of intensive English programs, teachers who would like to coordinate collaborative projects with other teachers, ESL/EFL teachers working with preschool children, elementary, secondary school, deaf students, and refugees) posted the following:
- questions and answers about teaching and learning English such as: how to become a teacher, teaching via Skype, grammar usage rules, improving students' accent, ideas for increased comprehension, communicative activities, how to reinforce language skills, problems in teaching pronunciation, speaking, reading, writing, grammar and others.

- discussion of issues such as activities and games that work well in the classroom, applied linguistics, assessment and testing of ESL/EFL students, aspects of bilingual education, ESP, ESL/EFL textbooks, materials writing, teaching business English, teaching TOEFL, IELTS, and TOEIC, teaching strategies, ideas on how to teach pronunciation, reading, writing and other language skills.

- videos such as: The teacher-a BBC English (video), Improve your conversation skills (video), English Writing lesson (video).

- links to website for free materials and resources, and language learning websites.

- information about English such as fun facts about the English language: simple grammar, interesting way to learn English idioms with "PIES".

- announcements about meetings, jobs vacancies, teacher surveys, online training, English language courses, important TESL/TEFL events, conferences, webinars, and workshops.

These findings are partially consistent with findings of a study by Bett and Makewa (2020) which found the Kenyan teachers' interactions on Facebook focused on the teaching of English and Literature, and other education-related issues only, since the focus of the study was on one Facebook group. Unlike the current study which revealed a wide range of topics posted in TFPs, the topics on which a Swedish teacher thematic Facebook group focused were less comprehensive than those in the current study. Lundin et al. (2020) reported that the posts Swedish teacher thematic Facebook group were questions and/or requests that focused on four themes: sharing, pedagogical ideas and premises, instructionally motivated technical features, and functionally motivated technical features.

Furthermore, the variety of topics posted on the ESL TFPs in this study are similar to those posted in professional online discussion forums for ESL teachers in studies by Al-Jarf (2014), Al-Jarf (2006a), Al-Jarf (2006b).

\section{ESL TFPs Related Distance Learning During Covid-19}

Analysis of the theme-based TFPs showed that $22 \%$ focus on online/virtual and home-based teaching, tutoring, recruitment, support, and mentoring (19\% \& $3 \%$ respectively) as in the following FRPs: Independent Online ESL Teachers; Online ESL Teaching: Recruitment, Mentoring \& Support; Online ESL Teaching Support South Africa; ESL British Online Teachers Staffroom; Teachers' Lounge for online ESL; Online ESL Teachers; Online ESL Teacher Success and Support; Independent Online ESL 
Teachers; Skilled and Hired Online ESL Teachers Group; Online ESL Teaching Jobs; ESL Teachers (Home-based) Philippines; ESL Teachers Philippines Hiring (ESL, HomeBased, Work from Home); Audio Class - Homebased ESL Online Teachers.

Participating teachers posted a limited range of topics about online/virtual and home-based teaching during the Pandemic such as how to use distance learning platforms, online ESL teaching, tutoring, recruitment, support, mentoring, success, audio class - homebased ESL online teachers and online ESL teaching jobs, discussing distance learning, online teaching, home-based teaching. In addition, content analysis did not reveal much difference in the topics posted in the online and home-based teaching TFPs than other general and theme-based TFPs. Very few topics related to the integration of Covid-19 issues in the ESL classroom and in language skills were posted in those TFPs. Content analysis did not reveal any integration of listening, speaking, reading and writing activities related to Covid-19 Pandemic in online learning.

\section{Advantages of Joining ESL TFPs}

Teachers' responses to the questionnaire-survey revealed several advantages of joining an ESL TFP. They indicated that the TFb's are online learning communities whose members include teachers from different countries and cultures, different ages, and years of experience (novice, experienced), different areas of specialties and educational levels. Membership is free. ESL TFP's can be accessed anytime, anywhere and as many times as they wish. It can be accessed from their smart phones, laptop, iPad, or Tablet. They serve as a means of communication and exchanging information among the FP members. They serve as a bulletin board for following up news, events, and activities in a quick and easy way.

In addition, the teachers indicated that the TFP members constitute a homogeneous group, and the climate of interaction is warm and positive. Members are very helpful. They can communicate problems and suggestions to other members. They can post requests for teaching strategies, materials, lesson plans, audio-visual aids, and teaching and learning problems any time and receive immediate responses and help from several members. Teachers can upload and download resources such as tests, video activities, suitable movies for the ESL classroom, ebooks, lesson plans, software, Powerpoint presentation, puzzles, and worksheets.

Moreover, the ESL TFPs enhance teachers' awareness of non-conventional ESL teaching issues such as: teaching business with no teaching certificate, Facebook penfriends, using songs in TEFL, ideas for teaching presentation with 600 students, testing private students at Euro levels, teaching in rural schools in China, online tutoring, using Taekwondo to teach English, teaching pre-literate students, stopping parrot training, and others.

During the Covid-19 Pandemic, the TFPs were relatively helpful in issues related to home-based teaching, online recruiting. But there was not much difference in the teaching materials, resources, teaching strategies, help with teaching and learning problems before the Pandemic and during the Pandemic.

The above findings are partially similar to those in prior studies in the literature. For example, Swedish mathematics and language teachers participating in 6 self-organized Facebook groups, used "questions" and "offers" more frequently $(88 \%)$. The teachers used the Facebook groups as a professional development resource, focusing their interaction on pedagogical content knowledge (Liljekvist et al., 2021). Teachers from Pakistan and Bhutan declared that teacher interaction on social networks and the use of digital resources play a central role in the introduction of innovative pedagogical practices of teachers, and teachers' interest in knowledge sharing and professional learning (Impedovo et al., 2019). In Lundin et al. (2020) study, the teachers displayed a variety of identities such as active and engaged teacher, a thematic expert, or a central group member. They indicated that teachers' competencies in using social media platforms for collective and constructive discussions need to be strengthened. There is a challenge in how to encourage more teachers to participate in professional groups to trigger discussions characterised by openness, debate, and constructive criticism.

The benefits of participating in a professional online learning community as revealed by teachers in the current study are similar to those revealed by participants in professional online discussion forums and professional groups on other social media such as Twitter (Al-Jarf, 2006a; Al-Jarf, 2006b; Al-Jarf, 2014; Al-Jarf, 2017; Al-Jarf, 2020a; Al-Jarf, 2020b)

\section{E. Effects on Attitudes}

In their responses to the questionnaire-survey, the teachers stated that the TFPs create a social interpersonal rapport among the participants. They foster communication among teachers, teacher support and greater involvement in English language teaching-learning and pedagogical issues. They provide opportunities for social presence, cognitive stimulation, and instructional exchange. They promote asynchronous self-directed learning and provide opportunities for in-depth teacher-to teacher interaction. Members are receptive, supportive, and inclusive of each other's ideas and attend to each other's needs. The TFPs are essential for the successful development of online learning communities.

As in the present study, teachers in a Swedish teacher Facebook group with 13,000 members indicated that the Facebook online community is professionally beneficial and/or valuable for information exchange and social support. They also reported that Facebook was relatively beneficial to their professional life (Bergviken Rensfeldt et al., 2018). In another study, Swedish teachers reported that they share teaching material and resources and give and receive emotional and professional support (Lundin et al., 2020). Moreover, teachers' responses to the survey questions about the impact of participating in ESL FTPs in this study are similar to students' and teachers attitudes towards professional discussion forums on the Internet and Online Learning Management Systems, and professional groups on 
other social media such as Twitter (Al-Jarf, 2005; Al-Jarf, 2006a; Al-Jarf, 2006b; Al-Jarf, 2006c; Al-Jarf, 2007a; AlJarf, 2007b; Al-Jarf, 2014; Al-Jarf, 2017; Al-Jarf, 2020a; AlJarf, 2020b).

\section{F. $\quad$ Shortcomings of TFPs}

Despite the many benefits of joining a TFP, there are some shortcomings. Only $22 \%$ of the participants in the sample are active on TFPs. They post issues, respond to queries, and share materials. The TFPs are socially opaque as $81 \%$ of the members use a nickname. $80 \%$ of the responses were compliments and not real comments. On some pages, $32 \%$ of the posts are not related to a TFP's main theme. Others are not related to ESL, i.e., non-educational issues such as ads, greetings, entertainment, contests, poetry etc. In some TFPs with a large number of followers, the volume of posts and responses is overwhelming. It is time-consuming to read and respond to the comments and queries from so many teachers.

Content analysis of the sample posts showed that teachers seem to be more interested in obtaining ready-made lesson plans, test questions, test results, extracurricular activities, and worry about supervisors' evaluations than training, and self-improvement, attending conferences and symposia, results of educational research, comprehensive evaluation, use of technology in teaching and others (4\% of the total posts). Finally, content analysis of the TFPs and teachers' responses showed that they have no efficient searching tool. It is difficult to locate a certain topic (old posts or a specific question).

The shortcomings of the TFPs revealed by content analysis and teachers' responses in the current study are different from those reported by Bergviken et al. (2018), who found some characteristics of the Swedish teachers' Facebook group that were disadvantaging, exploitative and/or disempowering forms of technological engagement because Facebook groups expose teachers to forms of 'digital labour', commercialisation of exchanges and predominance of individualised reputation-driven behaviours. There are also challenges related to sustaining faculty participation, engagement, and navigating the social media space effectively, especially for teachers who are novice social media users (Luo et al., 2020). However, the shortcomings of ESL TFPs in the current study are similar to those of professional discussion forums and professional groups on other types of social media such as Twitter (Al-Jarf, 2020; AlJarf, 2014; Al-Jarf, 2006a; Al-Jarf, 2006b), but they are partially consistent with professional communities in Online Course Management Systems (Al-Jarf, 2005; 2007a; Al-Jarf, 2007b).

\section{RECOMMENDATIONS}

Based on the multiplicity and variety of online learning communities, groups, and pages for ESL teachers available on Facebook, this study recommends that ESL teachers who wish to join an online learning community on Facebook be selective as it is time-consuming to join or browse through numerous FPs. They can select FPs with many members, or an FP that belongs to an organization. They may examine the content of the FP of interest to them by browsing through a sample of posts. The ESL TFP admins should state the page focus or aim clearly. To help ESL teachers join a particular TFP, orientation workshops and user guides may be used to introduce teachers to professional communities which will ultimately lead to better communication and interaction among members of the ESL profession. The teachers may pay attention to issues related to pedagogy, design, and community, as these were found by Iredale et al. (2020) to contribute to the effective use of social media in supporting the development of new teachers in all sectors of teacher education, including English language teaching in primary, secondary, and lifelong learning.

Since there is lack of FPs that target ESL teachers at the elementary, secondary or college teachers and lack of studies of ESL TFPs in Saudi Arabia, this study recommends that some expert ESL teachers create one or more general FPs for ESL teachers in Saudi Arabia, as well as ESL TFPs for remote teaching and learning during the Covid-19 Pandemic where issues and problems related to the teaching and learning of English in Saudi Arabia are discussed. ESL teachers' use of social media platforms for professional development in Saudi are still open for further investigation by future studies.

Since there was a shift from face-to-face instruction to online distance learning at schools and universities in all countries and all subject areas including language teaching, this study recommends that ESL TFPs focus more on online teaching strategies in ESL for all grade levels, how to use active online language teaching activities, how to engage students online and increase interaction and communication between the teachers and the students and among the students themselves. Teachers need to be guided in how to adapt the English language course material to online teaching material, how to supplement the online teaching with videos and Apps such as Kahoot, Slido, Vicaroo, Padlet, and podcasts, and how to assess students online fairly and effectively.

\section{REFERENCES}

Al-Jarf, R. (2020a). Issues in interactive translation practice on Twitter. $16^{\text {th }}$ International Scientific Conference eLearning and Software for Education. Bucharest, Romania. Vol 3, pp. 427-437. Retrieved from DOI: 10.12753/2066-026X-20-227.

Al-Jarf, R. (2020b). Communication among instructors and students via Twitter. In Irena Vassileva, Mariya Chankova, Esther Breuer and Klaus P. Schneider (eds.) The Digital Scholar: Academic Communication in Multimedia Environment, pp. 265-280. Frank \& Timme.

Al-Jarf, R. (2017). Exploring online collaborative translator training in an online discussion forum. Journal of Applied Linguistics and Language Research (JALLR), 4(4), 147-160.

Al-Jarf, R. (2014). ESL teachers' online discussion forums and professional development. ELTAM Journal, 1, 1-10. ERIC Number: ED613063.

Al-Jarf, R. (2007a). Cultural issues in online collaborative learning in EFL. In Meena Singhal and John Liontas (Eds.) Second and Foreign Language Teaching and Research. 77-83. https://www.researchgate.net/publication/287994289

Al-Jarf, R. (2007b). Online dialog among EFL college faculty: A comparison of two Saudi and Korean newsgroups. The $3^{\text {rd }}$ International Online Reading Matrix Conference on Second and Foreign Language Teaching and Research.

Al-Jarf, R. (2006a). Teachers' online discussion forums in Saudi Arabia. ERIC Number ED497499.

Al-Jarf, R. (2006b). Teachers' online discussion forums in Saudi Arabia. Imanager's Journal of Educational Technology, 3(2),49-54. https://doi.org/10.26634/jet.3.2.732 
Al-Jarf, R. (2006c). Using online dialogue to develop cross-cultural understanding. Iranian Journal of Linguistic Studies (IJLS), 1, 13-25. ERIC Number: ED494790.

Al-Jarf, R. (2005). Connecting students across universities in Saudi Arabia. 4th Asia CALL Conference. ERIC Number. ED497940.

Allela, M., Ogange, B., Junaid, M., Charles, P. Effectiveness of multimodal microlearning for in-service teacher training. Journal of Learning for Development. 2020; 7(3): 384-398.

Andersson, P. \& Köpsén, S. (2019). VET teachers between school and working life: boundary processes enabling continuing professional development. Journal of Education and Work, 32(6-7), 537-551.

Bedford, L. (2019). Using social media as a platform for a virtual professional learning community. Online Learning, 23(3), 120-136.

Benko, S., Guise, M., Earl, C., Gill, W. More than social media: using Twitter with preservice teachers as a means of reflection and engagement in communities of practice. Contemporary Issues in Technology and Teacher Education (CITE Journal). 2016; 16(1): 1-21.

Bergviken Rensfeldt, A., Hillman, T., Selwyn, N. Teachers' liking' their work? Exploring the realities of teacher Facebook groups. British Educational Research Journal. 2018; 44(2): 230-250.

Bett, H. \& Makewa, L. (2020). Can Facebook groups enhance continuing professional development of teachers? Lessons from Kenya. AsiaPacific Journal of Teacher Education, 48(2), 132-146.

Carpenter, J. \& Harvey, S. (2020). Perceived benefits and challenges of physical educators' use of social media for professional development and learning. Journal of Teaching in Physical Education, 39(4), 434444.

Chasteen, N., Cole, M., DeRoss, A. Expanding professional development opportunities for consultants: how to incorporate social media into a communication center. Communication Center Journal. 2019; 5(1): 113-119.

Goodyear, V., Parker, M., Casey, A. Social media and teacher professional learning communities. Physical Education and Sport Pedagogy. 2019 24(5): 421-433

Greenhow, C., Li, J., Mai, M. From tweeting to meeting: expansive professional learning and the academic conference backchannel. British Journal of Educational Technology. 2019; 50(4): 1656-1672.

Hardy, E. (2014). Teachers are doing it for themselves: using social media for professional development and advocacy. FORUM: for promoting 3-19 comprehensive education, 56(2), 265-276.

Harvey, S. \& Carpenter, J. (2020). Genesis and change in physical educators' use of social media for professional development and learning. Journal of Teaching in Physical Education, 39(4), 445-453.

Impedovo, M., Malik, S., Kinley, K. Global south teacher educators in digital landscape: implications on professional learning. Research on Education and Media. 2019; 11(2): 19-28.

Iredale, A., Stapleford, K., Tremayne, D., Farrell, L., Holbrey, C., SheridanRoss, J. A review and synthesis of the use of social media in initial teacher education. Technology, Pedagogy and Education. 2020; 29(1): $19-34$.

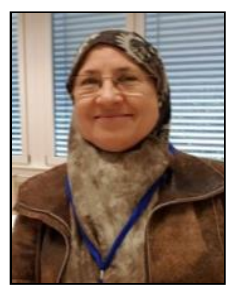

Reima Al-Jarf is professor of ESL, ESP, linguistics, and translation. She has 700 publications and conference presentations in 70 countries. Some of her articles are published in Web of Science and Scopus journals. Since the outbreak of the Covid-19 Pandemic, she has written and published 12 book chapters and journal articles. She reviews Ph.D. theses, promotion works, conference and grant proposals, and articles for numerous peer-reviewed international journals including some Web of Science and Scopus journals. She won 3 Excellence in Teaching Awards, and the Best Faculty Website Award at her university. Her areas of interest are: Foreign language teaching and learning, technology integration in education, and translation studies.
Lemon, N. \& O'Brien, S. (2019). Social media use in initial teacher education: lessons on knowing where your students are. Australian Journal of Teacher Education, 44(12), 38-56.

Liljekvist, Y., Randahl, A., van Bommel, J., Olin-Scheller, C. Facebook for professional development: pedagogical content knowledge in the centre of teachers' online communities. Scandinavian Journal of Educational Research. 2021; 65(5): 723-735.

Lundin, M., Lantz-Andersson, A., Hillman, T. Teachers' identity work in a professional Facebook group. Journal of Information Technology Education: Research. 2020; 19: 205-222.

Luo, T., Freeman, C., Stefaniak, J. "Like, comment, and share"--professional development through social media in higher education: a systematic review. Educational Technology Research and Development. 2020; 68(4): 1659-1683

Manson, S. \& Cordovés, J. (2018). \#Digitalfaith: using social media for professional development. Journal of College and Character, 19(1), 86-92.

Moodley, M. (2019). WhatsApp: creating a virtual teacher community for supporting and monitoring after a professional development programme. South African Journal of Education, 39, 2, Article 1323.

Murray, K. \& Ward, K. (2019). Attitudes to social media use as a platform for continuing professional development (CPD) within occupational therapy. Journal of Further and Higher Education, 43(4), 545-559.

Nicholas, B., Avram, A., Chow, J., Lupasco, S. Building a community of connected ELT professionals on Twitter. TESL Canada Journal. 2018, 35(2): 166-178.

Richards, K., Killian, C., Kinder, C., Badshah, K., Cushing, C. Twitter as a Professional Development Platform among U.S. Physical Education Teachers. Journal of Teaching in Physical Education. 2020; 39(4): 454-463.

Setiawan, H. \& Phillipson, S. (2020). The correlation between social media usage in academic context and self-efficacy towards TPACK of prospective science teachers in Indonesia. Journal of Science Learning 3(2), 106-116.

Slagoski, J. (2019). Professional learning practices and beliefs of an online community of English language teachers. Contemporary Issues in Technology and Teacher Education (CITE Journal), 19(1).

Suardika, I., Alberth; Mursalim; Siam; Suhartini, L., Pasassung, N. Using WhatsApp for teaching a course on the education profession: presence, community, and learning. International Journal of Mobile and Blended Learning. 2020; 12(1): 17-32.

Supovitz, J., Kolouch, C., Daly, A. The social psychology of homophily: the collective sentiments of education advocacy groups. Teachers College Record. 2020; 122 (6).

Torphy, K., Hu, S., Liu, Y. \& Chen, Z. Teachers turning to teachers: teacherpreneurial behaviors in social media. American Journal of Education. 2020; 127(1): 49-76.

Xue, S., Hu, X., Chi, X. \& Zhang, J. Building an online community of practice through WeChat for teacher professional learning. Professional Development in Education. 2021; 47(4): 613-637. 